\title{
Wealth-Based Trust and the Development of Collective Action
}

\author{
By: ERIC C. JONES*
}

(2004) E.C. Jones. Wealth-Based Trust and the Development of Collective Action. World Development 32(4):691-711.

Made available courtesy of Elsevier:

http://www.sciencedirect.com/science/journal/0305750X

****Note: Figures may be missing from this format of the document

\begin{abstract}
:
Interpersonal trust is one possible mechanism by which wealth inequality affects the success of efforts in cooperation. Specifically, the presence of perceived economic differences between members of small agricultural cooperatives in northwest Ecuador's agricultural frontier encourages trust in the wealthy, thus facilitating co-op development during the initial stage of cooperative formation. But, such inequality and exclusive trust may later negatively affect co-op success. These generalizations are only possible through refinement of frameworks currently used in the study of heterogeneity and common pool resource management. This refinement is made possible by paying closer attention to the operationalization of variables and by synthesizing already existing hypotheses.

Key words - common pool resources, cooperatives, heterogeneity, inequality, South America, Ecuador

\section{Article:}

1. INTRODUCTION

Humans cooperate under a variety of circumstances. In some cases, groups function under a set of formal or implied rules, often designed to regulate a collective good. In other cases, individuals pool their resources to accrue increased benefits under economies of scale. In either situation, collective action efforts are likely to be more successful when individuals identify with a common future (Ostrom, 1992) and develop strong interpersonal relationships (Portes \& Landolt, 2000). These hypotheses have inspired a litany of arguments that emphasize "social capital" or trust as factors necessary for success in people's efforts to cooperate. In addition, a growing consensus holds that another factor is implicated in the success of collective action: heterogeneity. Research to date has differentiated between economic and cultural heterogeneity, as each operates through different mechanisms (e.g., Baland \& Platteau, 1996). It is important, now, to investigate assertions about heterogeneity for the ways in which an institution's success depends on the strategic relationships of its members, since relationships between members are more important than the nature of the institution or general morals for the development of trust related to economic life (Granovetter, 1985, pp. 490-491) and because trust becomes more important where variability in information quality exists (cf., Bowles \& Gintis, 2002, p. 23), such as on the agricultural frontier.
\end{abstract}

This study examines interpersonal trust as a possible mechanism by which perceived wealth inequality affects the success of small farmer cooperatives in a northwestern Ecuadorian 
colonization zone, where social relations are rapidly forming anew. ${ }^{1}$ I propose that interpersonal trust between members allows for more successful cooperative functioning. Perceived wealth differences help predict the extent and direction of these trust relationships, although the effect of inequality varies over the co-op's life. Those cooperatives that are successful over time find ways to overcome divided social networks and build trust in spite of interindividual differences in terms of wealth.

\section{THE DEBATE ABOUT HETEROGENEITY AND COOPERATION}

There are many types of regulations, beliefs and behaviors that create conditions for the potential development and success of cooperation in managing common pool resources. According to Ostrom (1992) and Becker and Ostrom (1995), collective action is most successful when there is: (a) cultural homogeneity (assets, information, cost/benefit perceptions, preferences, and normsespecially reciprocity and trust), (b) small group size, (c) moderately strict rules, (d) low rates of discounting the future, (e) widespread participation, (f) accurate and low cost monitoring of behavior, and (g) legitimate maintenance of cultural norms. Agrawal (2002, pp. 62-63) synthesized seminal works in the field, including Ostrom (1990), Baland and Platteau (1996) and Wade (1988), to try and produce a coherent set of "Critical Enabling Conditions for Sustainability in the Commons" relating to: common pool resource system characteristics and group characteristics and the relationship between the two; institutional arrangements (rules and enforcement) and the relationship between the institution and common pool resources; and the environment external to both the user group and the resource (e.g., technology, markets, government). Among the group characteristics, a number of issues are important but the focus of the current study concerns the proximate mechanisms for the effect of wealth inequality on cooperative efforts.

Recently, research on heterogeneity's effect on cooperation has intensified. A wide variety of theoretical and empirical research has long found that cooperation is more likely to occur when in-group formation is based on homogeneity and conformity (e.g., Boyd \& Richerson, 1985; Nettle \& Dunbar, 1997; Ostrom, 1990). Wealth inequality - a specific kind of cultural heterogeneity - may, however, create a particular condition under which wealthier members take on a disproportionate economic responsibility in order to ensure the success of collective action (e.g., Olson, 1965, pp. 33-34; Ruttan, 1998; Ruttan \& Borgerhoff Mulder, 1999), or even the survival of fellow rural producers under ecological stress (Bollig, 1998, p. 147). This occurs primarily when the economy is poor rather than when resources are ample (Baland \& Platteau, 1997, p. 467) and when resource-extraction technologies are relatively expensive (cf. Baland \& Platteau, 1999, p. 780).

On the other hand, high wealth differences between individuals might discourage cooperation if poor members lose incentive to participate if benefits are too little (Baland \& Platteau, 1999, p. 777; Ruttan \& Borgerhoff Mulder, 1999), if extreme homogeneity discourages anyone from leading the initial investment of time and money (Molinas, 1998), or if the wealthy opt to exit. In addition, similarities in risk perception promote cooperation (Ostrom, 1992, p. 299). While common property may arise from the scale of economy in the production of some good, the rich may benefit less from this economy of scale and thus exit in search of higher benefits. In Las Golondrinas, I did note that many rich did not join cooperatives, and this was probably because they already had better outside alternatives. But I also noted that the wealthier peasants that 
joined cooperatives typically did not have vehicles that would allow them to move their own product and achieve a greater profit outside of the cooperative. ${ }^{2}$ Thus, as farmers, they may not have had many more potentially profitable uses of their time and effort, unless they were to sell their land. Quiggin (1993) recognized the importance of considering this context for collective action, specifically that other modes (such as private property) of interacting with the means of production may be dominant where common pool resource management develops.

Several studies have suggested a U-shaped relationship between economic inequality and commons management. In other words, both high wealth inequality and extreme equality in wealth were found to increase success, but moderate wealth differences produced decreasing success (see Bardhan, 2000 for south Indian irrigators). Nonetheless, there remain theoretical and empirical contradictions with other studies like those cited previously, and Agrawal (2002, p. 61) insists that theoretical ambiguity still plagues this question. In addition, large-N studies tend to ignore the very specific relationships of cooperators and how they bring about success or failure (Agrawal, 2002, p. 71). Finally, a review of large-N multivariate irrigation studies by Bardhan and Dayton-Johnson (2002) found a negative effect of heterogeneity on collective action. Although the study did not consider nor compare the life cycles of the institutions studied, it found that various collective action functions are affected differently by inequality and these functions also vary temporally in their salience. It is the object of the present study to address both of those pieces of the puzzle together-individual relationships and institutional life cycles.

Heterogeneity within the context of cooperatives is much less studied than is heterogeneity within the context of common pool resources. Among the few studies of heterogeneity in cooperatives, Banerjee, Mookherjee, Munshi, and Ray (2001) found in Indian sugar cooperatives that large wealth inequalities created regulatory inefficiencies, particularly when the burdens borne by poorer members were equal to the wealthier members who were benefiting more (i.e., lacking congruence). Preliminarily, it seems that wealth inequality is related in a complicated, yet somewhat predictable, way to the success of small farmer groups. In another study of cooperatives, the larger cooperatives involved in collectivized production in coastal Ecuador have faced increasing pressures toward individualized production (Phillips, 1993). One response in coastal Ecuador included wealthy members investing money in the cooperative, instead of time, by paying poorer members to do the formers' work. Although this began to create some animosity, the cooperative continued functioning. How that animosity might later evolve is an important question, and again relates to the life cycle of a cooperative. In another case, a milk cooperative in arid India, despite wealthy individuals benefiting more than poorer members, functioned well partly because the wealthier members shouldered a disproportionate share of the costs (Pandey \& Patthak, 1997, p. 104). ${ }^{3}$ These last two cooperatives did not arrive at this inequality or differentiation under the same conditions. The former was oriented toward communal production, while the latter focused on communal transport and wholesale for individual production.

\section{IS SYNTHESIS POSSIBLE?}

Theoretical and empirical studies point to varying levels and even kinds of wealth inequality that may improve or hurt cooperative efforts. Are low, medium or high levels of inequality expected to improve collective action and, more importantly, why? In addition, is it possible to resolve the 
contradiction between the above scenarios in order to answer why inequality affects efforts to cooperate?

Four main theoretical solutions have been posed in the literature by political scientists, economists and sociologists. One of the four solutions is that the local historical context for collective action is extremely important (Varughese \& Ostrom, 2001). In the case of cooperatives in Ecuador, internal and external constraints are also intricately linked to historical local conditions (Phillips, 1993), and on a frontier this means there are likely unique problems for pioneers to solve in creating functioning cooperatives. Varughese and Ostrom's (2001) data suggest that heterogeneity produces no predictable or necessary impact on collective action, i.e., that the effect is random. That study does not, however, consider the extent to which a local context resembles that of another site developmentally, in which case similar patterns in collective action responses should be expected. Questions ask "how does x affect y under a given context." What is needed is to link any given context to its historical trajectory and to its likely future incarnations.

Second, Heckathorn (1996) has posed such a developmental solution. His framework suggests that members encounter a specific and predictable evolution of social dilemmas over the lifecycle of the institution, not a single kind of problem for cooperation. This is because institutions face changing collective goods production functions over time (Marwell \& Oliver, 1993). Thus, predicting collective action outcomes requires an understanding of the changing conditions under which various types of heterogeneity can be detrimental or beneficial. The current study approximates this solution by comparing cooperatives at different stages of development. More case studies are needed to test Heckathorn's theory.

A third solution is proposed by Bardhan, Ghatak, and Karaivanov (2001) who argue it is important to distinguish between intragroup (all users) and intergroup (wealthy vs. poor) differences. They found that reduced intragroup inequality increases efficiency but that there is some level of intergroup inequality that might be necessary. This argument is intriguing and promising, though still underdeveloped and would benefit from insights gained in social psychology and human behavioral ecology. ${ }^{4}$ In the current study, the use of perceived wealth inequality and interpersonal trust as variables does help address some of these more cognitive aspects of group formation during cooperation.

A fourth solution is that economic differences are not a sufficient measure for predicting cooperation and that forms of social behavior affect the relationship between wealth inequality and economic efficiency/success in cooperation. Specifically, researchers propose that various forms of social relationships, such as trust (e.g., Knack \& Keefer, 1997 for macro-level data) or 'associational activity' (Narayan \& Pritchett, 1999 for micro-level data) are correlated with economic development or economic efficiency, but negatively correlated with inequality. Flora, Garcia Bravo, Butler Flora, and Andrango Bonilla (2001) similarily found that interlocking directorates of community organizations occurred in the villages with highest per capita wealth, although the study did not measure the relationship between wealth disparity and economic development. 
These four theoretical frameworks - context, institutional life cycles, ingroup/outgroup behavior, and social capital — might result in contradictory findings about the relationship between inequality and effective common pool resource management. ${ }^{5}$ They also might be reconcilable if we are better able to understand the proximate mechanisms through which wealth heterogeneity affects cooperative success. Thus, the data presented in this paper are examined briefly in the discussion in light of these four frameworks. Synthesis is sought where possible, since currently what is really needed in the study of collective action is a theory of inequality and the development of trust. Combining local context, organizational development over time, in/outgroup dynamics and other social relationships to study wealth heterogeneity and collective action should prove effective for producing hypotheses that are relevant to the actual experiences of agricultural cooperatives. Incorporating these advances into a single framework makes it possible to postulate a causal relationship between wealth inequality and collective action that invokes trust as a mediating variable. If in- groups occur even in the context of small cooperative groups (e.g., because of a lack of history together), and if wealth serves as a basis for power, then trustbased subgroup formation within new groups should be based to some extent on members' levels of perceived wealth. Members of new groups will trust wealthier members more since their wealth serves as a proxy for power in the absence of negotiated social relationships.

\section{COOPERATIVES AND COMMON PROPERTY REGIMES}

Establishing the theoretical similarities and differences between agricultural cooperatives and common pool resource user groups extends the reach of this study's findings regarding the intricate effects of economic inequality on the development of interpersonal relations, thus allowing cooperatives to serve as theoretical proxies for a variety of common pool resource user groups.

Fundamentally, cooperatives are bounded groups which maintain formal criteria for decisionmaking and membership, and whose members possess some common interests, including mutual economic benefit. ${ }^{6}$ Thus cooperatives meet the criterion of exclusion that characterizes common property. Common pool resource user groups are also relatively bounded and have at least implicit criteria for decision-making but, although they have common interests, mutual economic benefit might not be one of those common interests.

Egalitarian, small farmer cooperatives are constrained by the ability of the poorest members to contribute land, labor or capital, having the practical effect of a limited public good (subtractability) characteristic of common-pool resources. Cooperative egalitarianism also is similar to common property regimes in terms of what makes it work. Ostrom's $(1990$, p. 92) claim is that successful common pool resource governance requires congruence between investment rules and allocation rules. Trawich (2001) found support for this proportionality (toeach-according-to-what-they-invest) hypothesis among Peruvian irrigators. On the other hand, Dayton-Johnson (2000, p. 39) found considerable variation in congruence between Mexican irrigating groups, and suggests that this may relate to the different roles occupied by rich and poor individuals in the user groups. Theoretically, the congruence hypothesis should hold for cooperatives, since by definition no member accrues benefits disproportionate to their (albeit equal) investment of time and money in the cooperative. This egalitarianism often results in less variation between members in terms of benefits, unlike common-pool resources. But, cooperatives such as those in Las Golondrinas based on individualized production - instead of 
collectivized production - do create more variation in benefits since individuals produce as much as they can and then use the co-op to process or market their product. ${ }^{7}$ It is this variation in benefits that encourages the wealthy to take on the financial responsibility of getting collective action (such as a cooperative) started, thus producing different roles for rich and poor members.

The major similarity between cooperatives and common pool resources really is the nature of the collective asset itself. High-cost productive inputs or large indivisible assets in cooperatives are hard to maintain when rules are not enforced or are nonexistent, just as the sustainability of common pool resources is hard to maintain when rules, whether formal or informal, are not enforced or are nonexistent.

With the exception of some rapid-growth common pool resources such as shrimp fisheries (e.g., Johnson \& Libecap, 1982), the major difference between limited common-pool resources and cooperatives is that limited common-pool resources cannot grow at the rate at which the financial capital of a cooperative might grow, mostly because of the co-op function of pooling resources. This is only a theoretical distinction in the case of the current study, since growth in the cooperatives with which I worked did not produce significant working capital, even if growth in membership or in the number of activities undertaken was fairly high. Another difference includes the potential variation in governance regimes due to greater formality for cooperatives and often less formality for common pool resources (cf. Hackett, 1992).

Researchers have long proposed a variety of explanations for the development of formal economic institutions such as private businesses or cooperatives and for why organizations succeed or fail. Internal characteristics include assembling competent people (Leavitt, 1964), having effective team management (Blake \& Mouton, 1964), and the use of a problem- solving orientation (Blake, Shepard, \& Mouton, 1964). External characteristics include being linked efficiently to regional/national organizations that can provide support and markets since cooperatives must solve the same problems, in virtually the same ways, as their capitalist counterparts (e.g., Chayanov, 1991).

The negative effect of neoliberalism on Latin American cooperatives includes detriment to wages, working conditions and employment levels from competing in larger markets (Phillips (1993) for agricultural co-ops Ecuador, Olson (1999) for artesanal co-ops in Guatemala; see Thompson (1973, p. 12), after Francis (1955) for negative effects of market competition on cooperative labor patterns). Lack of transportation and training in cooperativism, common in pioneer communities, can cause reliance on middlemen and thus reduce profitability (Schwartz, 1987 for Guatemala). Fear of, or speculation about, government, military, business or local behaviors may cause members to abandon cooperatives as well (Schwartz, 1987). In summary, the literature on cooperatives has been interested in the external environment - in other words technology, government interactions, and the economic constraints for cooperative success (e.g., availability of credit, competition, cost of marketing, cost of distribution). The frontier, where these external factors result in very little variation, is thus a situation where we must pay more attention to the internal dynamics of cooperatives to explain variation in performance.

\section{STUDY SITE}


Since Las Golondrinas' settlement began in the early 1970s, it has become a town of around 5,000 inhabitants on the Guayllabamba River $80 \mathrm{~km}$ southeast as the crow flies from the capital of the coastal province Esmeraldas. Las Golondrinas is also the name of the colonization zone (about 40 x $40 \mathrm{~km}$ ) to which the town of Las Golondrinas serves as an entrepôt.

Increased difficulties in small-scale agriculture throughout Ecuador in the 1980s (Phillips, 1993) led to the exodus of families from the area and a continuing reversion of much of the land to haciendas and large-scale farming. Only a handful of the original 100+ families benefiting from land reform remain in the three allotment areas surrounding what would become the town of Las Golondrinas. The rest have sold their land and moved to Quito, Santo Domingo, other big cities, or back to their home province.

Formal agricultural cooperatives in Ecuador have a short history, especially on the Ecuadorian coast. ${ }^{8}$ Cooperatives on the Ecuadorian coast currently are oriented more toward private property and individualistic production than toward the diverse potentials presented by cooperativism, partly because of neoliberal changes in agrarian production and markets since the late 1980s (Phillips, 1993). In the Las Golondrinas colonization zone, 15 cooperatives have developed over the past 12 years, ${ }^{9}$ a time when large palm and palmito (for palm hearts) plantations have spread across the Las Golondrinas landscape. But locals say agricultural cooperatives have not been very effective in promoting the economic success of their members, citing high turnover in land ownership, a lack of cooperative marketing endeavors, and a lack of political/governmental support - particularly credit, to which they have little access. ${ }^{10}$ All of the cooperatives in Las Golondrinas appear to face similarly discouraging external factors.

\section{(a) Cooperative goals}

Most cooperatives in the Las Golondrinas area are primarily interested in processing, and almost all of them started out by seeking credit for the farm activities of individual members. Very few are concerned with technical support, export markets, or collectivized transport or production. This uniformity in cooperatives' foci owed partly to the fact that processing agricultural goods is where most value can be added to these products, instead of increasing production, finding specialized markets, or cutting out the middleperson. Farmers in these cooperatives note the potential of pooling capital to purchase equipment to process their produce (see Table 1).

People join the cooperatives in Las Golondrinas because they have a general notion that it will help them prosper agriculturally, although specifically, they have few concrete goals in common with fellow members when they join, except to try and get credit (credit is more favorable and easier to get through a cooperative; however, the coops that focus on credit have been the least successful in Las Golondrinas).

Agricultural cooperatives are not very common in the provinces from which the cooperativists overwhelmingly hail. Cooperatives in Las Golondrinas seem to be a brotherhood, a fraternity of sorts, a place to develop ties and trust. But not everyone trusts each other to the same extent. What is the effect of this variation in trust on the nature of cooperative development?

\section{(b) Cooperative life cycles}


Most of the cooperatives in the Las Golondrinas area sprang to life as farmers grouped together to seek credit either from the government or from NGOs. The problem of lack of capital has indeed limited cooperatives' ability to gain direct access to consumer markets, leaving them to focus on storable perennials and grains in order to have at least some control over prices at which they sell their harvest. The repayment of loans has been a harbinger of cooperatives in this area, although those who have kept their distance from paternalistic bureaucracies have thus worked less with credit and faced this problem less.

As agricultural cooperatives in Las Golondrinas mature, their exclusive interest in acquiring credit and cheaper inputs gives way to an interest in retailing products - both raw and valueadded products. Not surprisingly, mature, successful cooperatives show greater clarity concerning goals for their next projects. One hypothesis holds that relationships among members must also change over time, as the cooperative passes through different stages (cf. Heckathorn, 1996). According to the literature reviewed above, the model would be that wealthy take on the burden of co-op start-up, but that the process of developing common goals allows poorer members to be trusted more, since there is less of a need to place exclusive trust in the wealthy as leaders in the creation of vision for the cooperative.

Table 1. Characteristics of five agricultural cooperatives in this study

\begin{tabular}{lccccc}
\hline Cooperative & Crop focus & $\begin{array}{c}\text { Stage of production } \\
\text { focus }\end{array}$ & $\begin{array}{c}\text { Sought credit } \\
\text { first }\end{array}$ & Stage of development & $\begin{array}{c}\text { Next } \\
\text { project }\end{array}$ \\
\hline Jaime Ordoñez & Rice & Processing, retail & Yes & Mature & Rice dryer \\
12 de Octubre & Meat & Processing, retail, inputs & $?$ & Mature & Meeting hall \\
Febres Cordero & Rice & Processing, inputs & Yes & Early & Unclear \\
6 de Diciembre & Palm & Processing, inputs & Yes & Early & Credit \\
Los Limones & General & Processing, inputs & Yes & Middle/reform & Unclear \\
\hline
\end{tabular}

The lack of ability of the poor to contribute substantially to cooperatives is what Smith (1982, pp. 88-89) was concerned about when he studied Amazonian colonization. "Colonists generally recognize the intrinsic value of coops, but few trust each other enough, or can invest sufficient capital, to join and maintain one." Smith's statement about trust rings quite true for Las Golondrinas. In addition to the disintegrating pressures all Ecuadorian cooperatives face from neoliberal agricultural policies, and those pressures faced by coastal cooperatives due to individualistic production, producer cooperatives on the frontier must overcome the problems of pioneer existence in order to develop the trust and common goals necessary for success.

Under conditions of economic uncertainty and high in- and out-migration characteristic of a colonization zone, cooperative membership can change quickly, making it difficult for members to develop appropriate expectations and trust. Only 13\% of the original 122 settling families around the town of Las Golondrinas still own any of their land, and cooperatives have suffered because of this mobility that results in a list of nonactive members who are legally quite difficult to remove from the roles (author's notes). Unstable roles also make it difficult to achieve quorum to conduct business legally, and to develop and follow through on consistent, coherent, membersupported goals (i.e., sense of common future). ${ }^{11}$

Thus, the main pressures that these cooperatives face over time are the effects on trust and goal formation of both member migration and the move from interest in agricultural inputs to interest 
in product outputs. The change from inputs to outputs actually creates a change in the nature of the public good; the importance of the nature of the collective good for the effect of heterogeneity on collective action has been noted by various authors (e.g., Baland \& Platteau, 1997; Bardhan et al., 2001). Since cooperatives in my sample are at different stages in their development, and because institutions face changing collective goods production functions over time (Marwell \& Oliver, 1993), the current study serves as a proxy for the diachronic analysis of obstacles to cooperative success.

\section{METHODOLOGY}

The focus of this study is the impact of the density of trust relationships on cooperative success. The study also considers when economic differences are good predictors of the density of those trust relationships. The problem of inconsistent definition of concepts across studies compounds the already complicated study of collective action (Poteete \& Ostrom, 2002, pp. 17-19). Since the field of collective action (regarding common pool resources) still lacks good understandings of the nature of causal relationships between variables, improvement in the theoretical framework requires a multifaceted methodological approach. For the current study, ethnographic description, network level analysis and the analysis of individual-level data comprise this multifaceted approach. What follows is a detailed explanation of the sample and the operationalized variables.

\section{(a) Sample}

In order to test the relationship between wealth-based trust and cooperative success, Ianalyzed intracooperative social networks. Icollected data on 11 cooperatives and chose those cooperatives with sufficiently completedata sets for comparison, totaling five: JaimeOrdõnez, 12 de Octubre, Febres Cordero, 6 de Diciembre, and Los Limones.

The five cooperatives are representative of the 16 that have existed in Las Golondrinas in terms of success, focus, beginnings and trajectory, and size. Three of the five cooperatives have 15 members, all of which are active. Two of the cooperatives each have 25 members, of which between 15 and 20 are active. I eliminated inactive and least active members from the two larger co-ops in my dataset, in order to arrive at a uniform sample size for analysis of intra-cooperative trust networks (15 each), though analysis is also done in Table 6 with data obtained on all 25 members.

Along with four trained local assistants, I administered a structured interview to cooperative members requiring each interviewee to respond regarding each of his or her fellow cooperative members - one question regarding trust in each fellow member, the other regarding perception of each fellow member's wealth relative to his or her own. Another structured interview solicited actual wealth data. In addition to structured interviews, I was a participant observer attending most of the meetings of these cooperatives during 2000, and I conducted informal interviews with many cooperative members and noncooperativists in 1999 and 2000.

Interviews were conducted with 13 members of Jaime Ordõnez, 12 de Octubre and 6 de Diciembre, and twelve for Febres Cordero and Los Limones, since my assistants and I were unable to interview all cooperative members. This resulted in interviews with 63 individuals, and data for 75 co-op members. Since each member rated each of the 14 other members, average 
values (and thus codes) could be obtained for all 15 members in each cooperative, even when I was not able to interview all members. The networks with 12 interviews were normalized to be comparable to the networks with 13 interviews. I also used all of my interviews to analyze the effect for the two larger cooperatives ( 25 each), and discuss the effect in the sections including Tables 5 and 6 .

\section{(b) Success}

How should success be measured? The different goals of economists (i.e., efficiency) and sociologists and political scientists (i.e., institution-building) usually lead to different measurements of success. The problem becomes, "Is a group successful if they operate efficiently but create no institution that will survive social change over the long term?" Or conversely, "Is a group successful if they have a strong institution that serves as a fraternal organization with very few traditional economic benefits?" Various measures of success for economic studies, including actual behaviors, efficiency/ effectiveness, and rules for governing behaviors are presented in Table 2. This suite of measures is quite striking, since one of the great problems in social science is to figure out predictable combinations of norms, behaviors, and efficiency when studying any phenomenon.

Thus, prior studies used actual behaviors, rules for governing behaviors, and efficiency/ effectiveness of behaviors for operationalizing the success of collective action. I operationalized cooperative success by taking into consideration both institution-building and economically productive behaviors (see Table 3 ). The ordinal scale was based on each cooperative's material wealth, number of projects implemented relative to co-op lifespan (from their minutes), and the ratio of the number of business items in meetings vs. resolution of those items. Molinas (1998) used a similar aggregate measure of the success of peasant committees in Paraguay, but most studies use simple measures such as existence of rules for forest entry (Varughese \& Ostrom, 2001), efficiency of conservation (Baland \& Platteau, 1997), or hypothetical level of adherence to rules (Ruttan \& Borgerhoff Mulder, 1999).

Both quantitative measurements and ethnographic data indicate that Jaime Ordõnez is by far the most successful cooperative and 12 de Octubre a clear second, while the other three co-ops are less successful with relatively less variation between them. ${ }^{12}$ This ranking of the co-ops makes sense ethnographically. Based on my observations of meetings and informal interviews, Jaime Ordõnez members seemed most willing to put the most time aside for their cooperative. 12 de Octubre cooperative seemed to have clear goals and short, efficient meetings. Febres Cordero was an upstart cooperative that had a huge success with rice production the prior year, but had very few meetings in the off-season. The last two cooperatives met regularly, but really had undertaken very few projects. 6 de Diciembre seemed to have more consensus about their goals than did Los Limones, however. Nuances to this scale depend on the difference between institutional effectiveness and economic efficiency, as previously discussed. The effects of these different aspects of the scale are taken up in the results and discussion sections, especially regarding the placement of 6 de Diciembre and Febres Cordero.

\section{(c) Wealth}

How should wealth heterogeneity be measured? Although economists and sociologists disagree on the nature of models of economic efficiency, they share a concern for the effect of inequality 
on other aspects of society. Unfortunately, neither group of researchers has utilized consistent data-gathering techniques nor have they discussed the effects of utilizing the kinds of techniques that they employ (see Table 2). What is "high" inequality and what is "low" inequality? When measures are different, there is little basis upon which to generalize across studies. While many methodologies categorize people into two groups (e.g., rich/poor, high/ low), particularly for use in game theoretical constructs, the techniques employed for creating those two groups vary widely. Though studies often employ the same causal mechanism, they do not typically employ the same operationalization of a variable. Granted, the context of fieldwork and the theoretical agenda

Table 2. Measures of wealth heterogeneity and collective action success

\begin{tabular}{|c|c|c|c|}
\hline Study & $\begin{array}{l}\text { Measure of wealth } \\
\text { inequality }\end{array}$ & Measure of success & Theoretical mechanism \\
\hline Olson (1965) & $\begin{array}{l}\text { Proportion of productive } \\
\text { assets }\end{array}$ & $\begin{array}{l}\text { Level of collective goods } \\
\text { produced }\end{array}$ & $\begin{array}{l}\text { Wealthy take responsibil- } \\
\text { ity because have more to } \\
\text { gain (Olson effect) }\end{array}$ \\
\hline Molinas (1998) & $\begin{array}{l}\text { Gini (based on median } \\
\text { land value adjusted for } \\
\text { price which served as } \\
\text { proxy for land quality) }\end{array}$ & $\begin{array}{l}\text { Committee perfor- } \\
\text { mance }=\text { no. of activities, } \\
\text { individual participants, } \\
\text { member perception of } \\
\text { success, and emulation by } \\
\text { other peasant committees }\end{array}$ & $\begin{array}{l}\text { High and low disparity } \\
\text { discourage leadership, but } \\
\text { moderate amounts } \\
\text { encourage it (Molinas ef- } \\
\text { fect) }\end{array}$ \\
\hline $\begin{array}{l}\text { Ruttan and Borgerhoff } \\
\text { Mulder (1999) }\end{array}$ & $\begin{array}{l}\text { Owners of many } v s . \text { few } \\
\text { cattle (theoretical) }\end{array}$ & $\begin{array}{l}\text { Conservation for human } \\
\text { well-being }\end{array}$ & $\begin{array}{l}\text { Constraints on individu- } \\
\text { als' contributions (Olson } \\
\text { effect), game theory }\end{array}$ \\
\hline Ruttan (1998) & $\begin{array}{l}\text { Membership in one of two } \\
\text { castes }\end{array}$ & $\begin{array}{l}\text { Conservation for human } \\
\text { well-being }\end{array}$ & Olson effect \\
\hline $\begin{array}{l}\text { Varughese and Ostrom } \\
\text { (2001) }\end{array}$ & $\begin{array}{l}\text { Location, emic wealthyl } \\
\text { poor (land, livestock, food } \\
\text { surplus, remittances), emic } \\
\text { disparity; index of wealth } \\
\text { disparity; index of frac- } \\
\text { tionalization of caste/eth- } \\
\text { nic membership }\end{array}$ & Rules for entry/harvest & Local historical context \\
\hline $\begin{array}{l}\text { Baland and Platteau } \\
\text { (1997) }\end{array}$ & $\begin{array}{l}\text { Differences in economic } \\
\text { interests via wealth, access } \\
\text { to use rights, and credit } \\
\text { (theoretical) }\end{array}$ & $\begin{array}{l}\text { Efficiency of conservation } \\
\text { (theoretical) }\end{array}$ & $\begin{array}{l}\text { Olson effect, not allowing } \\
\text { variation in access to } \\
\text { mean variation in status in } \\
\text { community, low value of } \\
\text { commons (thus rich allow } \\
\text { poor to use CPRs equally } \\
\text { in stratified agrarian soci- } \\
\text { eties) }\end{array}$ \\
\hline $\begin{array}{l}\text { Baland and Platteau } \\
\text { (1999) }\end{array}$ & $\begin{array}{l}\text { Differences in social/eco- } \\
\text { logical/human production } \\
\text { factors for using CPR } \\
\text { (i.e., income; ratio of } \\
\text { credit restraints to boat } \\
\text { possession) }\end{array}$ & $\begin{array}{l}\text { Efficiency of resource } \\
\text { management (i.e., profit } \\
\text { per boat) }\end{array}$ & $\begin{array}{l}\text { Olson effect, Molinas ef- } \\
\text { fect; high inequality } \\
\text { encourages leadership by } \\
\text { rich, but discourages par- } \\
\text { ticipation by poor }\end{array}$ \\
\hline Baker (1998) & $\begin{array}{l}\text { Disparity in wealth distri- } \\
\text { bution }\end{array}$ & $\begin{array}{l}\text { success of community for- } \\
\text { est efforts }\end{array}$ & Molinas effect \\
\hline Bardhan (2000) & $\begin{array}{l}\text { Gini coefficient for land- } \\
\text { holding }\end{array}$ & $\begin{array}{l}\text { Cooperation in water } \\
\text { allocation and field chan- } \\
\text { nel }\end{array}$ & $\begin{array}{l}\text { Inequality discourages } \\
\text { cooperation, but some } \\
\text { evidence of U-shaped } \\
\text { relation }\end{array}$ \\
\hline Heckathorn (1996) & $\begin{array}{l}\text { Differences in economic } \\
\text { interest (theoretical) }\end{array}$ & $\begin{array}{l}\text { Level of collective goods } \\
\text { produced (theoretical) }\end{array}$ & $\begin{array}{l}\text { Evolving cost matrices of } \\
\text { games }\end{array}$ \\
\hline
\end{tabular}


Table 3. Ordinal ranking of cooperative success

\begin{tabular}{lcccc}
\hline Cooperative & Wealth & Projects & Meetings & Total \\
\hline Jaime Ordoñez & 5 & 5 & 5 & $\mathbf{1 5}$ \\
12 de Octubre & 4 & 4 & 4 & $\mathbf{1 2}$ \\
Febres Cordero & 3 & 3 & 1 & $\mathbf{7}$ \\
6 de Diciembre & 2 & 1 & 3 & $\mathbf{6}$ \\
Los Limones & 1 & 2 & 2 & $\mathbf{5}$ \\
\hline
\end{tabular}

of a researcher often determine the nature of measurement, but careful attention must be paid to the extent to which measurements provide enough robustness for comparing across studies. For now, studies might benefit from using more than just one measure of wealth inequality.

It was important for me to examine perceived wealth because it is a perceived access to resources and power that is likely an important factor for the development of trust in these situations, as well as an indicator of local dynamics of stratification. ${ }^{13}$ The use of perceived wealth to represent wealth inequality is a new approach (e.g., Scoones, 1995; Varughese \& Ostrom, 2001), while most researchers have used some material or occupational measure of the economic interest of individuals to represent heterogeneity. It is important to address both, since perception may be important for others' behaviors vis-à-vis you, but their own actual wealth can be quite important for their behavior that is directed at the cooperative's economic activities. In terms of the actual variation in wealth, some members had as little as a couple of bicycles and a couple of pigs, while others had as much as 300 ha and hundreds of cattle. Most had something like 10-50 ha or the wealth equivalent. When I adjusted each household's wealth level to account for its place in its life cycle, the shape of the income distribution remained similar.

Thus, one question on the cooperative survey was used to arrive at a measurement of members' perceived wealth within each cooperative. I acquired cooperative members' perception of fellow members' wealth (emic) by asking if each other member had more, the same, or less wealth than did they. ${ }^{14}$ I coded each of the responses of "less," "the same," and "more" as values of 1, 2 and 3 , respectively, and averaged all of scores given to each individual by fellow members.

To test the relationship between wealth and trust at the level of the dyadic relationship, as in Table 5, I used these average wealth scores as an ordinal scale ranging from 1.0 to 3.0. To examine the relationship between wealth-based trust and success in Table 6, I dichotomized the sample in each cooperative. I divided each cooperative into two groups due to small size of the membership and to test the idea that most people tend to think in terms of the fewest categories; i.e., rich and poor, rather than rich, middle and poor. I used the average perceived wealth score as the cutoff point for dichotomizing the sample in each cooperative. Those individuals above the average received a score of 1 (rich) and those individuals below the average received a score of 0 (poor).

\section{(d) Trust}

Finally, what aspect of a social relationship is important, and how should it be measured? Common proxies for social relations have been social cohesion or trust. Measures vary greatly across studies. Trust is certainly based on individual traits, although Portes and Landolt (2000) argue that social capital applies to groups, not individuals, and care must be taken to measure 
group attributes and not just individual attributes. One solution is the consideration of webs of interpersonal relationships that consider individual behaviors within a social context.

One question on the cooperative survey was used to elicit intracooperative trust networks for the computation of an ordinal ranking of members' trustworthiness within each cooperative. Cooperative members were asked to rate their level of trust in each of their fellow members on a scale of $0-100 \% .{ }^{15}$ Each person's mental scale is likely to be different. To control for this, I averaged the trust percentages received by each individual (0-100\%) from each of their fellow members. To analyze dyadic ties (data collected from each member about each other member), I used Spearman's Rho as a measure of correlation between the level of trust given by the interviewee to another person and the level of perceived wealth given by the interviewee regarding that person.

Each of the new, averaged individual scores that fell above their co-op's overall average percentage received a value of 1 (high trustworthiness), and those that fell below the co-op average received a value of 0 (low trustworthiness), in order to create the intracooperative trust networks by linking individuals through their high trustworthiness scores. In other words, individuals were graphically linked in Payek 0.69 (Batagelj \& Mrvar, 1996) in a network with all of their fellow members to whom they had given higher than average trustworthiness scores. This permitted me to count the relationships between any and all individuals. To analyze the relationship between average perceived wealth and average trust assigned to each individual, I used the same high (1) and low (0) trustworthiness values.

The three variables in this study, then, are individual wealth levels (perceived), trust in individuals (both average per individual and $\mathrm{N} x \mathrm{~N}$ ), and cooperative success. I have operationalized the variables wealth and trust ways so as to allow an analysis of the relationship between inequality and trust at the network level, the individual level and the level of the dyadic ties that make up each network.

\section{RESULTS}

In order to examine interpersonal trust as a possible mechanism by which wealth inequality affects the success of cooperatives, it is necessary first to establish the relationship between trust within each cooperative and the success of that cooperative.

\section{(a) Trust and cooperative success}

When attending the cooperative meetings, I found it much more pleasurable and full of camaraderie to be spending this time with the two most successful cooperatives than with the two least successful cooperatives, even when the successful cooperatives took longer. In the most successful cooperative, I watched the membership reprimand one of the officers who left the previous monthly meeting early to catch the last scheduled bus home. They let him know in a firm but gentle manner that he either should resign his position or figure out another way home next time. He decided to maintain his paid position as treasurer and apologized to the others and, as a result, there seemed to be no hard feelings. I joined them as they all went to lunch together to take a break during their several hour meeting. It seemed that I heard much more backbiting among members in some of the less successful cooperatives. 
Table 4 below presents the density of trust relationships (i.e., the ratio of high-trust rela tionships to the potential number of such relationships) for cooperatives, which are listed in order of success. The method of using higher-than-average trust scores in a limited universe of relationships should result in half of the relationships being higher than average and half lower than average, if scores are random. ${ }^{16}$

Thus, using the average trust score in each cooperative as the mid-point for dichotomizing the sample (high trust/low trust) should produce a value of 0.5 for each cooperative if the data are distributed normally, resulting in half of the relationships of each person to each other person being very trusting relationships, and half to be relationships characterized by low trust levels. What the variation here shows is a skewing of trust scores around the average. If a value of 0.5 is not obtained, then the data are skewed. Skewed data, in this case, indicate whether people trust most people a lot and a few people less, or few people a lot and most people less. As seen in Table 4, the three least successful cooperatives produced values close to this expected value of 0.5. But, the two most successful cooperatives produced higher (i.e., skewed) trust values, indicating that their members tended to trust several people a lot and only a few people did they trust less. Thus, members of the higher density co-ops trust most people a lot and a few people a little, supporting the anecdotal observation of greater backbiting in the less successful cooperatives. So, who are the objects of that high trust in the less successful cooperatives?

\section{(b) Wealth and trust}

What explains variation in trust levels on the frontier, where people are just getting to know one another and develop expectations? This part of the investigation concerns the relationship between wealth differences and interpersonal trust. Although this relationship requires

Table 4. Network density of five study cooperatives, in rank order of success

\begin{tabular}{lccc}
\hline Cooperative & Rank order of success & Possible no. of dyadic ties & $\begin{array}{c}\text { Network density (ratio of no. of } \\
\text { dyadic ties to possible no. of } \\
\text { dyadic ties) }\end{array}$ \\
\hline Jaime Ordoñez & 1 & 181 & 0.76 \\
12 de Octubre & 2 & 182 & 0.66 \\
Febres Cordero & 3 & 136 & 0.54 \\
6 de Diciembre & 4 & 141 & 0.50 \\
Los Limones & 5 & 142 & 0.47 \\
\hline
\end{tabular}

systematic quantitative analysis, it does seem that a great deal of respect is afforded some of the wealthier residents on the Las Golondrinas frontier. For example, the names of most store owners and larger resident farmers (which does not include nonresident plantation owners) are heard frequently in conversations with residents and I do not remember very many instances that their names were spoken of with contempt or disrespect or even envy. While there exists a rhetoric of classlessness on the frontier, behaviors and preferences indicate that there is a tendency to trust the rich more than the poor when living in a situation characterized by both a heavier reliance on wage- labor relations and decreased information about your neighbors (cf. Jones, 2003). 
Table 5 presents the correlation between wealth scores and trust scores given by each individual to every other individual (i.e., correlation of $\mathrm{N} x \mathrm{~N}$ matrices, with total possible number of ties as in Table 4). ${ }^{17}$

Using only 15 members in each cooperative, just one of the correlations is positive, large enough to be a factor, and significant. It is a new cooperative, Febres Cordero - the most successful new cooperative economically, yet least successful institutionally. For the last two cooperatives, two different values are given: the first for 15 members, the second for 25 members. When all 25 members of each of 6 de Diciembre and Los Limones are used for the same analysis, however, the correlations both become significant, although low, as can be seen in the table: 0.324 ( $\mathrm{p}$ 0:001) for 6 de Diciembre and $0.222(p=0: 008)$ for Los Limones.

Table 6 presents the correlation between average individual perceived wealth scores and average individual trust scores, using 15 members from each cooperative. Using average scores helps to get at the social character of a group, in that cooperative members may change their response toward each other based on what their fellow group members think or do. By considering the effect of the opinions and behaviors of others, we are no longer left to rely upon a person's hypothetical, decontextualized feelings about each fellow member, as in Table 5. A simple way to do this is by averaging all the scores each person receives from fellow co-op members for trust and for perceived wealth. To examine the relationship in each cooperative between average perceived wealth and average trust of each individual, I dichotomized both wealth (rich, poor) and trust (high, low). The totals were placed in $2 \times 2$ dissimilarity matrices and the equation $\mathrm{d}=$ $(a+d)=(a+b+c+d)$, with cell counts analyzed including (i) rich-high trust, (ii) rich-low trust, (iii) poor-high trust, and (iv) poor-low trust. Each cooperative has 15 members, and thus the cells in each matrix total 15. Random distribution should produce scores around 0.5. Relationships showing high trust for rich and low trust for poor should produce higher

Table 5. Correlation between an interviewee's perception of each fellow member's wealth with the level of trust that the interviewee affords to each of those members other members, by cooperative

\begin{tabular}{lcc}
\hline Co-op, in order of success & Spearman's $\rho$ & $p$-Value \\
\hline Jaime Ordoñez & -0.129 & 0.096 \\
12 de Octubre & 0.025 & 0.737 \\
Febres Cordero & 0.244 & $0.004^{*}$ \\
6 de Diciembre & $-0.234 ; 0.324$ & $0.057 ; 0.001^{*}$ \\
Los Limones & $-0.046 ; 0.222$ & $0.730 ; 0.008^{*}$ \\
\hline
\end{tabular}

* Statistically significant.

Table 6. Dissimilarity matrices for each cooperative, using individual average perceived wealth by average trustworthiness of individuals

\begin{tabular}{|c|c|c|c|c|c|c|c|c|c|c|}
\hline & \multicolumn{2}{|c|}{ Jaime Ordonez } & \multicolumn{2}{|c|}{12 de Octubre } & \multicolumn{2}{|c|}{ Febres Cordero } & \multicolumn{2}{|c|}{6 de Diciembre } & \multicolumn{2}{|c|}{ Los Limones } \\
\hline & High & Low & High & Low & High & Low & High & Low & High & Low \\
\hline Rich & 3 & 4 & 4 & 3 & 7 & 1 & 6 & 4 & 5 & 3 \\
\hline \multirow[t]{2}{*}{ Poor } & 3 & 5 & 4 & 4 & 3 & 4 & 2 & 3 & 1 & 6 \\
\hline & \multicolumn{2}{|c|}{$\Delta=0.53$} & \multicolumn{2}{|c|}{$\Delta=0.53$} & \multicolumn{2}{|c|}{$\Delta=0.73$} & \multicolumn{2}{|c|}{$\Delta=0.60$} & \multicolumn{2}{|c|}{$\Delta=0.73$} \\
\hline
\end{tabular}




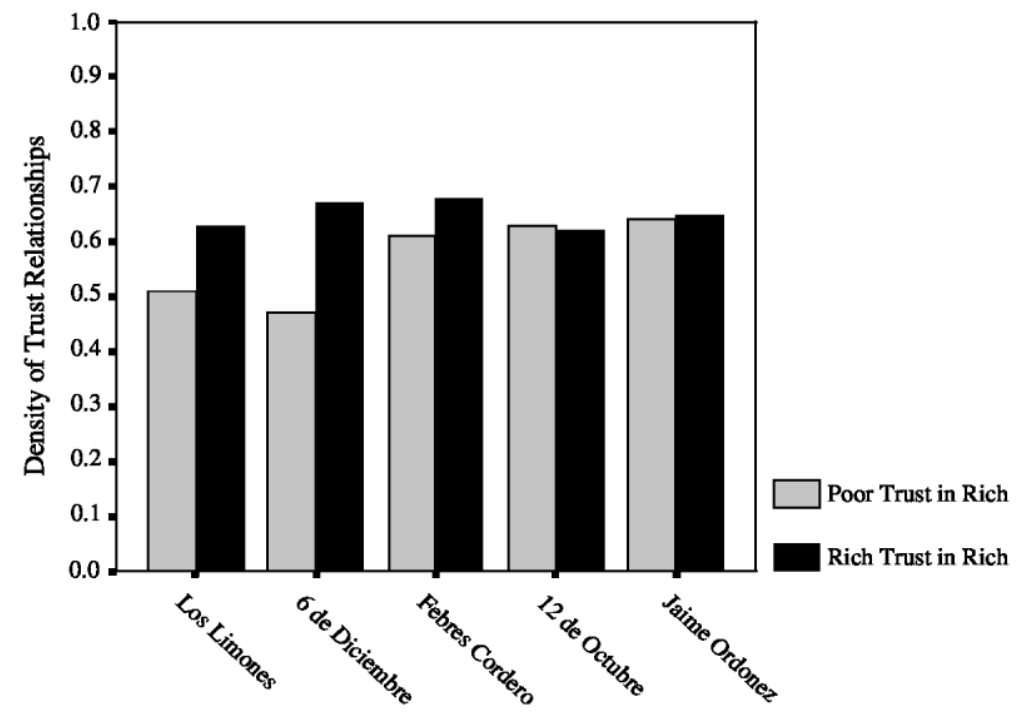

Figure 1. Density of trust networks directed at the rich. Density is relatively uniform across cooperatives for both the poor-to-rich and the rich-to-rich networks. Observed ties between rich members are divided by total possible ties between rich members. Observed ties where poor cite rich as trustworthy are divided by total possible ties from poor to rich. Total possible ties are less than theoretically possible ties, due to missing data.

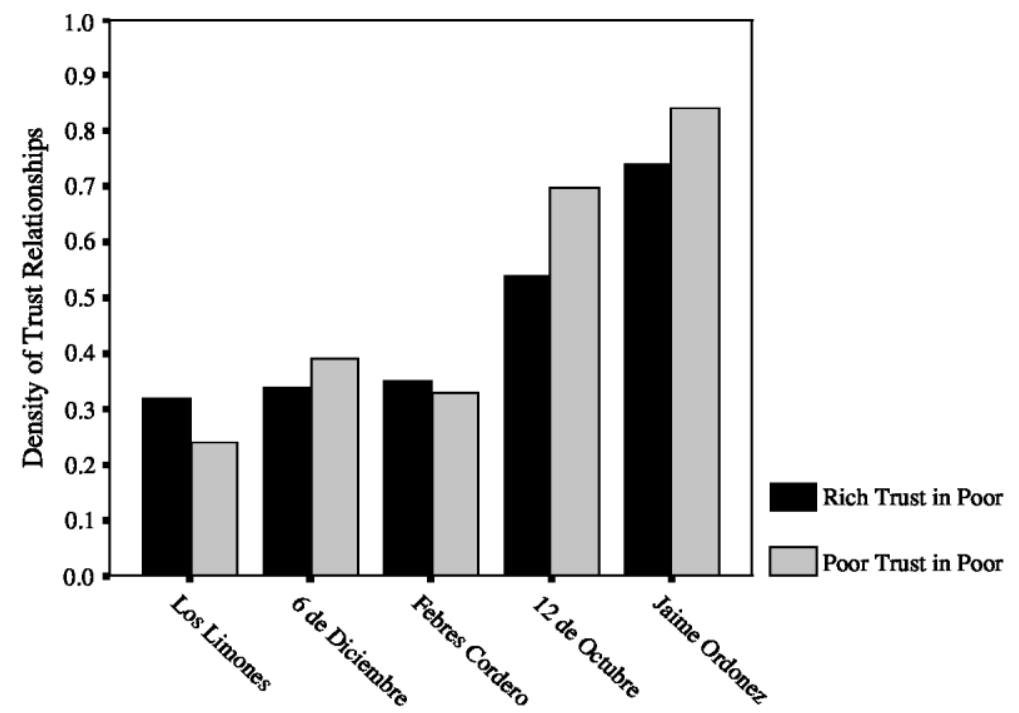

Figure 2. Density of trust relationships directed at the poor. Trust in the poor by the rich and by the poor is higher for the two most successful cooperatives and lower for the three cooperatives that are alike in their low degree of success. Observed ties between poor members are divided by total possible ties between poor members. Observed ties where rich cite poor as trustworthy are divided by total possible ties from rich to poor. Total possible ties are less than theoretically possible ties, due to missing data.

scores, as can be seen for the three less successful cooperatives.

From these scores, the three newer and least successful cooperatives have the highest dissimilarity values, which suggests that social dynamics in these cooperatives are more likely to produce a link between average perception of somebody's wealth level and the level of trust they are afforded. The two older and most successful cooperatives have values very close to the 
expected random value of 0.5 . One reason that 6 de Diciembre has a lower measure of dissimilarity than the two other newer cooperatives is that eight of its 15 active members had prior experience in other cooperatives; perhaps their experience allows them to dissociate trust from how they perceive the wealth (i.e., power) of other members within this context. But, when considering the entire 6 de Diciembre cooperative, whose membership is formed of people who do not know one another and come from all over the area, the dissimilarity measure increases.

This variation between cooperatives regarding the relationship between trust and wealth level spurs two hypotheses: (1) people with less experience in cooperatives are more likely to base their trust on wealth, and (2) people who do not know each other use wealth as a means of deciding whom to trust. While hypothesis \#1 appears to be an individual level characteristic, it is the presence of several experienced co-op members interacting that allows for trusting attitudes. Hypothesis \#2 is also less of an individual characteristic than it appears, since the decision of whom to trust is a social process.

Both hypotheses dovetail with the idea that cooperative development over time faces particular challenges at particular times. Of course, individual cooperative members tended to sound more trusting when asked a hypothetical question such as "Would you loan your fellow members money?" But, responses such as "Yes, I'd help a compañero if they asked" insinuate that certain members likely would never ask them for assistance.

The above test relies on aggregate measures, not on how individuals perceive and then trust each other individual or not. When such a test is performed on how each individual perceives and then trusts each other individual, as in Table 5, only the new cooperative that is charging ahead economically, but possibly failing institutionally, experiences a relationship between these variables at the interpersonal level. This supports hypotheses about collective action start-up and usefulness of exclusive power of some individuals for efficiency, but such preliminary conclusions require an understanding brought about by the analysis of dyads, networks, and even group attitudes. In the next section, network-level relationships between wealth and trust characterize a model for the relationship between wealth-based trust and cooperation.

\section{(c) A model of wealth-based trust and cooperative success}

There exists little variation between co-ops when considering trust relationships that are directed at rich cooperative members, as can be seen in Figure 1 which is based on the number of dyadic ties shown in Table 4. What that means, specifically, is that most of the variation between co-op trust network density and cooperative success seen in Table 4 does not come from relationships in which the rich are the objects of trust. This supports the picture painted by Tables $4-6$, but shows more specifically what is the source of variation.

The variation in Table 4, then, comes from relationships in which poorer members are cited as trustworthy, as can be seen in Figure 2. Both wealthy and poor members vary similarly regarding the increase in success that accompanies the increase in trust network density within each cooperative. Certainly in the many meetings I attended of each cooperative, it seemed that wealthier members in the newer coops had the floor more of the time than in the older, more successful co-ops where both wealthy and poor individuals seemed to share the floor roughly the same amount. 
Who are the people that are trusted more than anyone else in each of these cooperatives? Are they wealthy or poor? Based on the wealth levels of the most highly respected 3-5 people in each cooperative, the most successful cooperatives tended to give both more responsibility (i.e., official duties) and more interpersonal trust to poorer individuals than to wealthy individuals. The tendency was the opposite for the less successful cooperatives.

\section{DISCUSSION}

The four theoretical frameworks proposed for synthesis at the beginning of this paper must now be evaluated in light of the results. First, context does appear important for the success of cooperatives, but not such that the effect of inequality becomes random. Specifically, whether cooperatives began by their own initiative or that of the government appears to affect success, but not at the exclusion of the effect of wealth inequality on success. Second, knowing the stage in the life cycle of a cooperative is useful for predicting when wealth differences will be most important, particularly due to the effect of migration and changes in the importance of inputs vs. outputs mainly on goal formation and trust. Third, wealth inequality, or the variation in members' actual wealth, is greatest for the three most successful cooperatives, suggesting that wealth inequality may, along with developing trust, continue to play a role in cooperative performance after start-up. Fourth, social relations serve as more than a proxy for economic strategies, but efforts to cooperate are affected by wealth differences. The model proposed in the results seems to be able to incorporate all of these hypotheses. Of course, further questions remain about the relative contributions of each of these hypotheses to a theoretical framework regarding the development of trust under conditions of wealth heterogeneity.

\section{(a) The beginnings of a theory on inequality and trust formation}

Why does everybody always trust the rich in these cooperatives, whether old or new or successful or unsuccessful? Is it because they are the early leaders due to start-up costs, or because they can afford to always fulfill their obligations, or because wealth serves as a proxy for power (i.e., "money talks")? Regarding start-up costs, it seems reasonable that performance by the rich would translate into trustworthiness, but it is more dubious that early contributions really assure permanent high status. Of course, if the rich do not act in a trust-creating fashion (i.e., taking on the responsibility of early start-up), then the co-op does not even get off the ground, supporting Olson's (1965) original argument about the potentially positive effect of heterogeneity. Regarding the fulfillment of obligations, my observation is that the wealthy have fulfilled their general obligations to these cooperatives no more nor any less than have the poor.

This leaves the question of whether wealth serves as an initial proxy for power. This proposition is supported by the fact that the newer cooperatives trust the rich while older and more successful cooperatives trust both the rich and the poor, even placing poor into positions of power. This confirms Massey, Freeman, and Zelditch (1997) (cited in Kopelman, Weber, \& Messick, 2002, p. 129) finding that people judge higher status individuals' acts more favorably than they do similar status individuals if those higher status individuals' rationales are valid, but also much less favorably than those of similar status if the higher status peoples' rationales are invalid. To complement that finding, the implication produced by this study is that greater familiarity between individuals, the lower is the strength of those tendencies. Similarly, in a study using a 
game producing individual economic rewards, Glaeser, Laibson, Scheinkman, and Soutter (2000) found that social distance (e.g., ethnic differences) decreased trust and trustworthiness.

So, why do people not trust the poor in the newer cooperatives? Is it because they cannot contribute much materially to the cooperative early on, or because of a stereotype that the poor are lazy until they prove themselves otherwise? The lower classes are less explicit about their goals and fuzzier in their plans for achieving their goals (Casagrande, Thompson, \& Young, 1964), due in no small part to the lack of availability of capital. Yet the rich do join with these poor people who have less commitment to specific goals. The rich even stay in cooperatives with people who have few resources. Hunt (1992) suggests that the reason for rich participation in collective action may be a division of labor that is more productive. Ethnographic data from Febres Cordero give some indication of how this division of labor works. A couple of rich Febres Cordero members talked as if they were interested in helping the really poor members in their co-op, or at least as if they had sympathy for them. But, the cooperative planned to cultivate collectively the next season, paying poorer members to do the labor. This puts rich and poor into separate relations of production (employer, employee), and membership might be used to enforce work compliance. Whether that is a good or bad thing really depends on the situation.

\section{(b) Levels of analysis}

Looking more closely at levels of analysis can help clarify the relationship between inequality and cooperation. The use of ethnographic information, individual-level measures and group-level measures are important for sorting out potentially confusing results. First, group- level network density seems to be related to group success. But, perceived wealth may or may not be correlated with trust when examining dyadic ties within each cooperative, since it seems to have a strong relationship in only one of the cooperatives. Since an individual's average trust is more closely linked with their average perceived wealth in the newer cooperatives, then it appears that the very strong reliance on perceived wealth for developing trust shows up in the one new cooperative that has been most successful economically thus far.

At the individual level in the campo, I would not necessarily expect an association between the exact choices of whom to trust and those persons' socioeconomic status, this being due to the highly connected and complicated nature of rural society. There emerges, however, a more notable structuring of relationships through wealth-based trust networks in the case of a new cooperative, because the cooperative requires leadership and it requires consolidation of goals. Basically, people in cooperatives do not trust each other individual in a vacuum, even if a survey shows that they do. While I may trust you, your trustworthiness depends on how much others trust you in relation to how much others are trusted. Perhaps this is because those joining the cooperatives typically do not have a long history of working together and because of the absence of strong egalitarian mechanisms when the cooperative is first formed.

One hypothesis seeking a more ultimate explanation might be that individual human tendencies toward subgroup formation are necessary even in cooperative situations, such that there must be subgroups for the larger institution to provide enough reliability in member behavior ("our subgroup acts like this, their subgroup acts like that") for the group to sustain its coherence. At some point, a sort of class-consciousness (e.g., an in-group/outgroup dynamic) becomes a 
negative factor for cooperative performance. If only dyadic relationships were examined, it might be impossible to explore this potential explanation.

\section{(c) Remaining questions}

Do people become wealthy through participation in a cooperative, or why do people join? On the whole, members are hopeful about the future, and it seemed that members of the new cooperatives were even more hopeful, despite their criticisms of the current condition of their institution, than members of established co ops. In addition to their hope for the future, however, I saw fraternal camaraderie and bantering in all of the cooperatives to be at least as important to members as any efficiency or high productivity at meetings. This was accompanied by a language of cooperativism - always referring to each other as compañero- which was more noticeable in the successful cooperatives, even during heated debates.

Some alternative hypotheses should also be considered for cooperative success. Are crop focus, age of cooperative, group size, prior experience, leadership, time together or legal status responsible for cooperative success? It does appear that the most successful groups are smaller, have been together longer, have legal status, and produce crops requiring low capital inputs; also, time knowing each other through village life or physical proximity does seem to have some positive effect, but not as much as does experience with cooperativism. High trust in leadership occurs in all of these cooperatives, but more telling is whether leaders are highly trusted and involved in reciprocal relationships. Finally, although familiarity with cooperativism may not alone guarantee success in cooperativism on the frontier (see also Farmer, 1957, p. 297), 6 de Diciembre - and its several members with prior cooperative experience - had a more uniformly dense social network than did Febres Cordero which has been more successful economically. In any case, all of these hypotheses complement the thesis of this study, rather than displace it.

Still, the question must be asked: Does trust cause success or is it success that causes trust? It may be not only that wealth inequality promotes lopsided trust between wealthier and poorer members, which in turn produces failure, but also that trust comes about through successful activity together. One scenario of how cooperation might develop in managing a common pool resource is that a group of wealthier individuals disproportionately bear the costs of forming a cooperative in anticipation of benefits. They seek out some poorer individuals to amass the people and interest necessary to start a cooperative. At first, social networks characterized by trust in someone's word/deed are likely to be based on wealth. In fact, newer, less successful cooperatives in Las Golondrinas still demonstrate subgroups based on wealth. Over time, cooperatives are able to succeed, at least in part, by overcoming the tendency of humans to form relationships based on power or on relative/perceived access to resources (i.e., wealth). If a cooperative is not able to develop more inclusive relationships to counteract class-consciousness or antagonistic class relations, a cooperative may fail, leaving only those that have successfully confronted the challenge over time.

Reliance on wealth-based trust by members of new cooperatives means that wealthy members generally are trusted by rich and poor to the same extent regardless of time and place, but that poor members are not. Rather, trust in the poorer members is associated with co-op success. The direction of this relationship is likely mutual and circular, where success improves trust and trust improves success. But, one prediction made for this study was that exclusive trust in the wealthy 
is a factor that allows for co-op start-up. All three of the newer co-ops in the study exhibited this tendency. The most successful of the three new co-ops was foremost in exhibiting this tendency. In the long term, however, all members in these newer cooperatives must come to trust poorer members if the cooperative is to succeed.

\section{CONCLUSION}

This research on trust relationships contributes to an understanding of the conditions under which wealth contributes to exclusivity within small bounded social networks, called negative social capital by Portes and Landolt (2000, p. 533). Although these five cooperatives are similar in terms of general economic orientation, they vary in terms of the effect of perceived wealth on the structure of their trust networks, as well as the subsequent effect of trust networks on success. The extent to which these relationships result in economic inefficiencies or social disruption, however, seems to depend on circumstances related to the life cycle of the institution. Individual wealth is a salient and important variable for the development of a group's dynamics. Although wealthy individuals (and institutions) often attempt to maintain their wealth at the expense of others, co-ops might actually be held together by perceived inequalities under certain conditions (Pandey \& Patthak, 1997; cf. Phillips, 1993). It is in new group situations that greater trust in wealthier members might improve the prospects of collective action. This provides the basis for a theory of inequality and trust formation to supplement a larger framework concerning collective action.

Future studies of collective action would benefit from this emphasis on actual relations of production, in addition to the power and prestige created by wealth differences. Experimental studies, however, have focused on game theory and frameworks incapable of representing the capital-labor relationship. Thus, it is important to investigate whether it is wealth (relational and/or tactical power) or relations of production (structural power) that is responsible for individual behavior in economically heterogeneous groups. There is good reason to believe that class-consciousness, even in the social realm, is uncommon among peasants because of the lack of economic pressures to divide classes (e.g., Jones, 2003), such as employer/employee relations and value-adding activities.

Research should also examine whether formal organizations with wealth discrepancies must necessarily equalize wealth (or, perhaps, cause the rich or poor to exit) in order to overcome the disjointed networks. Perhaps it will be necessary in the future to find a measure for success that combines both efficiency and institution-building. This is particularly important when considering the addition of a diachronic framework like Heckathorn's (1996) where long-term change is relevant. Finally, it remains necessary to investigate other potential mechanisms for achieving interpersonal trust or other specific instantiations of social behavior that may serve as intervening factors between need and behavior.

\section{NOTES}

1. Though not the agricultural frontier, Grieco (1998) studied the formation of social networks of recent Indian migrants to Fiji, and found that group and family migration resulted in stronger ties than did individual and labor migration.

2. Even some of the intermediaries buying and selling agricultural products in Las Golondrinas did not have their own vehicles, but rent a truck when they had a full load 
ready. It is reasonable to call these farmers relatively wealthy or rich because of the gap between them and other peasants, as well as because of the value of the cultivated land that they possess.

3. Braverman, Guasch, Huppi, and Pohlmeier (1991, p. 6) similarly studied how wealthier individuals in rural Netherlands took on the responsibility of cooperative start-up, followed later by poorer individuals who contributed less.

4. The field of social psychology has done some work on ingroup/outgroup differentiation, with variation in the degree of differentiation of each group depending on majority/minority status (Bettencourt, Charlton, \& Kernahan, 1997), socioeconomic status (Sedikides, 1997), and expectations (Gaertner, Rust, Dovidio, Bachman, \& Anastasio, 1994).

5. Agrawal (2002) has begun to develop equations that take into account the effects of these apparently contradictory relationships.

6. Requirements for agricultural cooperative membership in Ecuador are: ID card, voting card, not belonging to another cooperative of the same kind or married to someone who is, title to property and, of course, acceptance to membership by the cooperative (Corporación de Estudios y Publicaciones, 2000, p. 01828, RgLCoo). All cooperatives must reelect their officers annually. In Ecuador, asociaciones have similar objectives but are governed by slightly more lenient laws. I considered both asociaciones and cooperativas as cooperatives. Of the five groups in this study, 12 de Octubre and 6 de Diciembre are asociaciones; members are not required to be landowners.

7. Individualized production means that labor is generally carried out by a member and their family or paid help. The collective aspects of cooperatives in Ecuador tend to involve processing, marketing or infrastructure. Most credit is not collective, but the cooperative has served as an easy vehicle for the distribution of government loans on an individual basis.

8. The first law of cooperativism was codified in 1966. Pockets of cooperatives often were associated with beneficiaries of land reform in the 1970s, since formal organization gave access to government assistance with credit and markets.

9. All but one Las Golondrinas co-ops started around 1990 (supported by the government's Integrated Rural Development Project), or 1999, when Ecuadorian currency devalued from 5,000 sucres to 30,000 sucres per US dollar (capped at 25,000 sucres) and caused input prices to soar.

10. Those successful at accessing credit were associated with the Integrated Rural Development project (DRI) of the early 1990s. Recently, several others were part of a union of cooperatives seeking to solicit credit to produce African palm for export to Taiwan.

11. On the other hand, the national law's constraints on getting rid of members does allow for co-ops to be resurrected easily, as well as serve as de jure proxy for yet unlegalized village councils. None of the cooperatives examined here have problems meeting quorum, but some of the others in the area do.

12. These names are pseudonyms.

13. Other researchers have employed emic wealth ranking techniques. For example, Varughese and Ostrom (2001) used emic indicators of wealth stratification among community forest users in 17 communities. Scoones (1995) used pile sorting to ascertain local wealth rankings. Nonetheless, although the question I posed to individuals used the 
word "recursos," the use of emic wealth ranking without further cognitive research on the domains of prestige and resources admittedly does not do much to distinguish wealth as resources vs. wealth as prestige.

14. Each member was asked about every other member of their cooperative, "?Tiene (name of fellow cooperative member) mas, igual, or menos recursos que usted "

15. The question used was, "Entre cero y cien porciento? Que tan confiable es name of fellow cooperative member?" or "Between zero and one hundred percent, how trustworthy is name of fellow cooperative member?" The word I used in Spanish to elicit the trust of one individual in another is confiable, which concerns the extent to which someone will do what they are expected to do or have promised to do. In other words, "Are they good for their word?" The notion of trust is potentially problematic, especially if relying only on an emic understanding of it. For example, one interpretation is that the rich trust the poor when the poor follow the lead of, or subjugate themselves to, the rich. My experience does not rule this out. Nonetheless, this idea is still theoretically compatible with the reason why I chose to ask about trust the way that I did, which is that locals emphasize the characteristics of trust that I was interested in-namely, reliability and judiciousness.

16. I counted relationships in the networks by hand, after using Payek 0.69 (Batagelj \& Mrvar, 1996) to depict the networks graphically. Missing data were given average values from existing data in order to produce comparable matrices between the five cooperatives. But, the elimination from the network matrices of people not interviewed produced similar results $(0.7,0.6,0.6,0.5,0.5)$ with UCI-NET V (Borgatti, Everett, \& Freeman, 1999).

17. Simple linear regression calculated by SPSS 9.0 (SPSS Science, 1998). As described in the methodology, each cooperative was dichotomized by the median. Thus, each cooperative has eight rich and seven poor scores, and eight high-trust and seven low-trust scores.

\section{REFERENCES}

Agrawal, A. (2002). Common resources and institutional sustainability. In E. Ostrom, T. Dietz, N. Dolsak, P. C. Stern, S. Stonich, \& E. U. Weber (Eds.), The drama of the commons (pp. 4185). Washington, DC: National Academy Press.

Baker, J. M. (1998). The effect of community structure on social forestry outcomes: insights from Chota Nagpur, India. Mountain Research and Development, 18(1), 51-62.

Baland, J. M., \& Platteau, J. P. (1996). Halting degradation of natural resources: is there a role for rural communities. Oxford, UK: Clarendon Press.

Baland, J. M., \& Platteau, J. P. (1997). Wealth inequality and efficiency in the commons, part I: the unregulated case. Oxford Economic Papers, 49, 451-482.

Baland, J. M., \& Platteau, J. P. (1999). The ambiguous impact of inequality on local resource management. World Development, 27(5), 773-788.

Banerjee, A., Mookherjee, D., Munshi, K., \& Ray, D. (2001). Inequality, control rights and rent seeking: sugar cooperatives in Maharashtra. Journal of Political Economy, 109(Feb.), 138190.

Bardhan, P. (2000). Irrigation and cooperation: an empirical analysis of 48 irrigation communities in south India. Economic Development and Cultural Change, 48(4), 847-866. 
Bardhan, P., \& Dayton-Johnson, J. (2002). Unequal irrigators: heterogeneity and commons management in large-scale multivariate research. In E. Ostrom, T. Dietz, N. Dolsak, P. C. Stern, S. Stonich, \& E. U. Weber (Eds.), The drama of the commons (pp. 87- 112). Washington, DC: National Academy Press.

Bardhan, P., Ghatak, M., \& Karaivanov, A. (2001). Inequality and collective action. In Paper prepared for the Conference on inequality, collective action, and environmental sustainability, September. Sante Fe NM: Santa Fe Institute.

Batagelj, V., \& Mrvar, A. (1996). Payek 0.69. Available: http://vlado.fmf.unili.si/pub/networks/pajek/, Ljubljana, Slovenia.

Becker, C. D., \& Ostrom, E. (1995). Human ecology and resource sustainability: the importance of institutional diversity. Annual Review of Ecological Systems, 25, 113-133.

Bettencourt, B. A., Charlton, K., \& Kernahan, C. (1997). Numerical representation of groups in cooperative settings: social orientation effects on ingroup bias. Journal of Experimental Social Psychology, 33, 630-659.

Blake, R. R., \& Mouton, J. S. (1964). The managerial grid: Key orientations for achieving production through people. Houston: Gulf Publishing Co.

Blake, R. R., Shepard, H. A., \& Mouton, J. S. (1964). Managing intergroup conflict in industry. Houston: Gulf Publishing Co.

Bollig, M. (1998). Moral economy and self-interest: kinship, friendship, and exchange among the Pokot (N.W. Kenya). In T. Schweizer \& D. R. White (Eds.), Kinship, networks, and exchange (pp. 137-157). Cambridge: Cambridge University Press.

Borgatti, S. P., Everett, M. G., \& Freeman, L. C. (1999) UCINET 5.0 Version 1.00. Natick: Analytic Technologies.

Bowles, S., \& Gintis, H., 2002. Persistent parochialism: The dynamics of trust and exclusion in networks. Unpublished manuscript, December 28. University of Massachussetts, Amherst. Available: http://wwwunix.oit.umass.edu/ gintis.

Boyd, R., \& Richerson, P. J. (1985). Culture and the evolutionary process. Chicago: University of Chicago Press.

Braverman, A., Guasch, J. L., Huppi, M., \& Pohlmeier, L. (1991). Promoting rural cooperatives in developing countries: the case of sub-Saharan Africa, World Bank Discussion Papers, No. 121. World Bank, Washington, DC.

Casagrande, J. B., Thompson, S. I., \& Young, P. D. (1964). Colonization as a research frontier: the Ecuadorian case. In R. D. Manners (Ed.), Process and pattern in culture: Essays in honor of Julian H. Steward. Chicago: Aldine.

Chayanov, A. V. (1991). The theory of peasant cooperatives [Translated by D. W. Benn]. Columbus: Ohio State University Press.

Corporaci on de Estudios y Publicaciones (2000). Ley de cooperativas: reglamento y legislación conexa. Quito: Corporacion de Estudios y Publicaciones.

Dayton-Johnson, J. (2000). Choosing rules to govern the commons: a model with evidence from Mexico. Journal of Economic Behavior and Organization, 42(1), 19-41.

Farmer, B. H. (1957). Pioneer peasant colonization in Ceylon: A study in Asian agrarian problems. London: Oxford University Press.

Flora, J. L., Garcia Bravo, M., Butler Flora, C., \& Andrango Bonilla, S. (2001). Community sustainability in an Ecuadorian landscape: the role of economic, human, environmental and social capital. 
In R. E. Rhoades (Ed.), Bridging human and ecological landscapes: Participatory research and sustainable development in an andean agricultural frontier (pp. 291-313). Dubuque, IA: Kendall/Hunt.

Francis, E. K. (1955). In search of Utopia: The Mennonites in Manitoba. Glencoe: Free Press.

Gaertner, S. L., Rust, M. C., Dovidio, J. F., Bachman, B. A., \& Anastasio, P. A. (1994). The contact hypothesis: the role of a common ingroup identity on reducing intergroup bias. Small Group Research, 25(2), 224-249.

Glaeser, E. L., Laibson, D. I., Scheinkman, J. A., \& Soutter, C. L. (2000). Measuring trust. Quarterly Journal of Economics, 115(3), 811-846.

Granovetter, M. (1985). Economic action and social structure: the problem of embeddedness. American Journal of Sociology, 91(3), 481-510.

Grieco, E. (1998). The effects of migration on the establishment of networks: Caste disintegration and reformation among the Indians of Fiji. International Migration Review, 32(3), 704-736.

Hackett, S. C. (1992). Heterogeneity and the provision of governance for common-pool resources. Journal of Theoretical Politics, 4(3), 325-342.

Heckathorn, D. D. (1996). The dynamics and dilemmas of collective action. American Sociological Review, 61(April), 250-277.

Hunt, R. C. (1992). Inequality and equity in irrigation communities. In Paper presented to International Association for the Study of Common Property 17- 20 September, Washington, DC.

Johnson, R. N., \& Libecap, G. D. (1982). Contracting problems and regulation: the case of the fishery. American Economic Review., 72(5), 1005- 1022.

Jones, E. C. (2003). Class-based social networks in regional economic systems. Research in Economic Anthropology, 22, 3-23.

Knack, S., \& Keefer, P. (1997). Does social capital have an economic payoff? A cross-country investigation. Quarterly Journal of Economics, 112(4), 1251- 1288.

Kopelman, S., Weber, J. M., \& Messick, D. M. (2002). Factors influencing cooperation in commons dilemmas: a review of experimental psychological research. In E. Ostrom, T. Dietz, N. Dolsak, P. C. Stern, S. Stonich, \& E. U. Weber (Eds.), The drama of the commons (pp. 113-156). Washington, DC: National Academy Press.

Leavitt, H. J. (1964). Managerial psychology; an introduction to individuals, pairs, and groups in organizations (2nd ed.). Chicago: University of Chicago Press.

Marwell, G., \& Oliver, P. (1993). The critical mass in collective action: a micro-social theory. New York: Cambridge University Press.

Massey, K., Freeman, S., \& Zelditch, M. (1997). Status, power, and accounts. Social Psychology Quarterly, 60(3), 238-251.

Molinas, J. R. (1998). The impact of inequality, gender, external assistance and social capital on local level cooperation. World Development, 26(3), 413-431.

Narayan, D., \& Pritchett, L. (1999). Cents and sociability: household income and social capital in rural Tanzania. Economic Development and Cultural Change., 47(4), 871-897.

Nettle, D., \& Dunbar, R. I. M. (1997). Social markers and the evolution of reciprocal exchange. Current Anthropology, 38(1), 93-99.

Olson, M. (1965). The logic of collective action: Public goods and the theory of groups. Cambridge, MA: Harvard University Press. 
Olson, J. M. (1999). Are artesanal cooperatives in Guatemala unraveling? Human Organization, 58(1), 54-66.

Ostrom, E. (1990). Governing the commons: The evolution of institutions for collective action. Cambridge: Cambridge University Press.

Ostrom, E. (1992). The rudiments of a theory of the origins, survival, and performance of common- property institutions. In D. W. Bromley, D. Feeny, M. A. McKean, P. Peters, J. L. Gilles, R. J. Oakerson, C. F. Runge, \& J. T. Thomson (Eds.), Making the commons work: Theory, practice and policy (pp. 293-318). ICS Press: San Francisco.

Pandey, V. N., \& Patthak, A. (1997). Peasants, subsistence and the dairy co-operative in dry land: A fragile existence. Economic and Political Weekly, 27, 98-105.

Phillips, L. (1993). Co-operatives and agrarian transitions in coastal Ecuador: Implications for neo- liberalism. Canadian Review of Sociology and Anthropology, 30(4), 429-450.

Portes, A., \& Landolt, P. (2000). Social capital: promise and pitfalls of its role in development. Journal of Latin American Studies, 32(2), 529-547.

Poteete, A., \& Ostrom, E. (2002). In pursuit of comparable concepts and data about collective action. In Paper presented to the CAPRi Workshop on Methods for Studying Collective Action. Nyeri, Kenya, 25 February-1 March, Available: www.capri.cgiar.- org.

Quiggin, J. (1993). Common property, equality, and development. World Development, 21(7), $1123-1138$.

Ruttan, L. (1998). Closing the commons: cooperation for gain or restraint? Human Ecology, 26(1), 43- 66.

Ruttan, L., \& Borgerhoff Mulder, M. (1999). Are East African pastoralists truly conservationists? Current Anthropology, 40(5), 621-652.

Schwartz, N. B. (1987). Colonization of northern Guatemala: The Peten. Journal of Anthropological Research., 43(2), 163-183.

Scoones, I. (1995). Investigating difference: Applications of wealth ranking and household survey approaches among farming households in southern Zimbabwe. Development and Change, 26(1), 67-88.

Sedikides, C. (1997). Differential processing of ingroup and outgroup information: The role of relative group status in permeable boundary groups. European Journal of Social Psychology, $27,121-144$.

Smith, N. J. H. (1982). Rainforest corridors: The transamazon colonization scheme. Berkeley, CA: University of California Press.

SPSS Science (1998). SPSS 9.0 for Windows. Chicago: SPSS, Inc.

Thompson, S. I. (1973). Pioneer colonization: a cross- cultural view. In Addison Wesley Module in Anthropology, (Vol. 33). Reading, MA.

Trawich, P. B. (2001). Successfully governing the commons: Principles of social organization in an Andean irrigation system. Human Ecology, 29(1), 1-25.

Varughese, G., \& Ostrom, E. (2001). The contested role of heterogeneity in collective action: some evidence from community forestry in Nepal. World Development, 29(5), 747-765.

Wade, R. (1988). Village republics: Economic conditions for collective action in South India. San Francisco, CA: ICS Press. 